\title{
Higher Education Quality Assurance and Accreditation Implementation in Several Countries across the World and Lessons Learned for Vietnam
}

\author{
Cuong Huu Nguyen ${ }^{1,+}$, \\ Stephen J. Marshall' ${ }^{2}$, \\ Collin W. Evers ${ }^{2}$
}

\section{Article History}

Received: 20 December 2020

Accepted: 5 March 2021

Published: 30 March 2021

\section{Keywords}

Quality assurance, accreditation, higher education, emerging system

\author{
${ }^{1}$ Ton Duc Thang University, Ho Chi Minh City, Vietnam; \\ ${ }^{2}$ The University of New South Wales (UNSW Sydney), Australia \\ ${ }^{+}$Corresponding author $\bullet$ Email: nguyenhuucuong@tdtu.edu.vn
}

\section{INTRODUCTION}

Quality assurance in higher education has grown dramatically since the 1980s. It has come to affect every level of the sector and has become an accepted and integral part of the higher education community (Williams \& Harvey, 2015). Over 100 countries and territories around the world have established national higher education quality assurance mechanisms. These systems aim to ensure quality control (minimum standards) in higher education, accountability and transparency, quality enhancement, and the facilitation of student mobility (Brown, 2004; Lim, 2001). Among the variety of quality assurance approaches, accredition has been most widely implemented.

In the context of Vietnam, quality assurance with accreditation as the key approach was officially introduced into the higher education system nearly twenty years ago. During the establishment and development of its higher education quality assurance and accreditation system, Vietnamese quality assurance framework and policies have heavily been influenced by Western and Eastern quality assurance such as Europeam Bologna processes, U.S. accreditation processes and ASEAN University Network - Quality Assurance (AUN-QA) assessment processes (Pham, Nguyen, \& Nguyen, 2019). This paper first analysizes quality assurance and accreditation policies and practices currently implemented in several countries across the world - Australia, France, Indonesia and the United States. Based on this analysis and the lessons learned from these quality assurance systems, it then proposes recommendations for the future development of Vietnam's emerging quality assurance and accreditation system.

\section{LITERATURE REVIEW}

\subsection{Concepts of quality assurance and accreditation}

Concepts of quality assurance and accreditation are various. For example, Campbell and Rozsnyai (2002, p. 32) define quality assurance as "an all-embracing term covering all the policies, processes, and actions through which the quality of higher education is maintained and developed". According to Harvey (2004-20), quality assurance in higher education has become a generic term used as shorthand for all forms of external quality monitoring, evaluation or review. 
Regarded as the most widely used quality assurance approach, accreditation is defined as "a process of external quality review created and used by higher education to scrutinize colleges, universities, and programs for quality assurance and quality improvement" (Eaton, 2015, p. 1). Two forms of accreditation have been developed and implemented. Institutional accreditation is usually based on an evaluation of whether the institution meets specified minimum (input) standards related to staff qualifications, research activities, student intake and learning resources. Institutional accreditation is normally undertaken by national bodies either government departments or governmentinitiated agencies that make formal judgements on recognition or whether accreditation will be granted. Institutional accreditation tends to focus on the overall infrastructure, especially the physical space, IT and library resources, and staffing. In addition, institutional accreditation might focus on financial arrangements and viability, governance and regulation, and administrative support. Program accreditation, on the other hand is the process whereby a program may be accredited for its academic standing or it may be accredited to produce graduates with professional competence to practice; usually referred to as professional accreditation (Harvey, 2004).

\subsection{Processes of quality assurance and accreditation}

Quality assurance is often considered as a part of quality management. According to Vlăsceanu, Grünberg, and Pârlea (2007), quality assurance involves the processes of assessing, monitoring, guaranteeing, maintaining, and improving the quality of a higher education system, institutions, or programs. Focusing on the accreditation process, Harvey (2004) points out that accreditation involves a set of procedures designed to gather evidence to enable a decision to be made about whether the institution or program should be granted accredited status.

More specifically, the accreditation process generally consists of three steps: (1) a self-evaluation (or selfassessment, or self-study) process conducted by the administrators, lecturers and staff members of the educational institution or study program, resulting in a report (commonly called self-evaluation report) that takes as its reference the set of standards and criteria of the accrediting agency; (2) a study visit (normally called onsite visit), conducted by a panel of peers, selected by the accrediting agency, which reviews the evidence, visits the premises, and interviews the academic and administrative staff, students and alumni, resulting in an assessment report, including recommendations to the accrediting organization; and (3) an examination by the accrediting organization of the evidence and recommendations on the basis of the given set of criteria concerning quality and resulting in a final judgement and the communication of the formal decision to the institution and other constituencies, if appropriate (Vlăsceanu et al., 2007).

\subsection{Purposes of quality assurance and accreditation}

Quality assurance procedures can serve two major purposes: improvement and accountability (Kis, 2005). For accreditation, its role in higher education, therefore, "is to help ensure a level of acceptable quality across the wide array of programs and institutions in higher education" (Hegji, 2017, p. 1). According to Harvey (2004), accreditation has three purposes. Firstly, accreditation as a process applied to applicant organizations. Secondly, accreditation is the label that institutions or programs may acquire as a result of the accreditation procedures. Thirdly, accreditation is an abstract notion of a formal authorizing power enacted via official decisions about recognition. It is this abstraction that gives accreditation its legitimacy.

In addition, the U.S. Department of Education (2021) lists the following as some of the purposes of accreditation:

- assessing the quality of academic programs at institutions of higher education;

- creating a culture of continuous improvement of academic quality at colleges and universities and stimulating a general raising of standards among educational institutions;

- involving the faculty and staff comprehensively in institutional evaluation and planning;

- establishing criteria for professional certification and licensure and for upgrading courses offering such preparation.

Furthermore, the Council for Higher Education Accreditation (CHEA) specifically identifies the following roles or purposes of accreditation: assuring quality, providing access to federal and state funds, engendering private sector confidence, easing of transfer of credits (Eaton, 2015).

\section{RESEARCH METHODS AND RESULTS}

\subsection{Research methods}

This study employed document analysis - a systematic procedure for reviewing or evaluating documents, which can be used to provide context, generate questions, supplement other types of research data, track change over time and corroborate other sources. Documents for qualitative research take a variety of forms, including: advertisements, agendas, scientific papers, books, organizational or institutional reports, and various public records (Bowen, 2009). According to Merriam and Tisdell (2016), document analysis can be used as a standalone method in social sciences research. 
The study used purposeful sampling, which is "based on the assumption that the investigator wants to discover, understand, and gain insight and therefore must select a sample from which the most can be learned" (Merriam \& Tisdell, 2016, p. 96). Consequently, the researchers collected documents discussing quality assurance and accreditation in the United States of America, Europe and the Asia-Pacific region. These regions were selected because Vietnam is situated in South-East Asia and its higher education system has been heavily influenced by the systems of the US and Europe. The documents collected were journal articles, book chapters, conference papers and academic reports published by governments, quality assurance networks or accreditation agencies.

\subsection{Research results}

\subsubsection{Accreditation in the United States}

Over 100 years ago, accreditation in the United States emerged from mounting concerns over the protection of public health and safety and service of the public interest. The US accreditation system is the oldest in the world (Eaton, 2015). This system provides both quality assurance (by assuring threshold levels of performance in higher education) and quality improvement (by assuring that higher education institutions and programmes maintain processes of improvement) (Eaton, 2015). In the United States, accreditation is overseen by both private, non-profit organisations and federal and state government agencies. As a result, the US accreditation structure is decentralised and complex and mirrors the decentralisation and complexity of higher education in America (Eaton, 2015; U.S. Department of Education, 2021). United States accreditation is characterised by "a trust-based, standards-based, evidence-based, judgement-based, peer-based process" (Eaton, 2015, p. 5).

In the United States, both federal and state governments consider accreditation a reliable authority on academic quality. The federal government relies on accreditation to ensure institutional and programme quality when distributing federal funds and student aid (Eaton, 2015). There are two basic types of accreditation in the United States: 'institutional' and 'specialised' or 'programmatic'. Institutional accreditation applies to an entire institution and evaluates the contributions of each of an institution's parts in the achievement of that institution's objectives. Institutional accreditation is overseen by regional and national accreditors. Specialised or programmatic accreditation typically applies to programmes, departments, or schools within institutions. The unit seeking accreditation may be as large as a college or school within a university or as small as a course within a discipline. Most specialised or programmatic accreditors review units within an institution of higher education already accredited by a regional or national accreditor (U.S. Department of Education, 2021).

The United States hosts four types of accrediting organisations (called accreditors): regional accreditors, national faith-related accreditors, national career-related accreditors, and programmatic accreditors. As of August 2020, seven regional accreditors accredit public and private, mainly non-profit and degree-granting, two- and four-year institutions. Five national faith-related accreditors accredit religiously affiliated and doctrinally based institutions, which are typically non-profit and degree-granting. Seven national career-related accreditors accredit mainly forprofit, career-based, single-purpose institutions that can be both degree and non-degree granting. Finally, approximately 80 programmatic accreditors accredit specific programmes, professions and freestanding schools in fields such as law, medicine, engineering and health. These accreditors review not only American higher education institutions and programmes, but also those in other countries (CHEA, 2020; Eaton, 2015). Specifically, US accreditation has been adopted in South America, Western and Eastern Europe, East Asia, the Middle East and Africa (Ramírez, 2015). Accreditation organisations receive funded from four sources: (1) annual dues from accredited institutions and programmes, (2) fees from institutions and programmes for accreditation visits, (3) financial assistance from sponsoring organisations, and (4) special initiatives funded by government or private foundations (Eaton, 2015).

Each American accreditor must undergo a periodic external review known as 'recognition'. Recognition is carried out by either the Council for Higher Education Accreditation (CHEA), a private organisation acting as a national coordinating body for institutional and programmatic accreditation, or the United States Department of Education (USDE). The CHEA and USDE recognise many, but not all, of the same accrediting organisations. Accreditors seek CHEA or USDE recognition for different reasons.

CHEA recognition confers an academic legitimacy on accrediting organizations, helping to solidify the place of these organizations and their institutions and programs in the national higher education community. USDE recognition is required for accreditors whose institutions or programs seek eligibility for federal student aid funds (Eaton, 2015, p. 8).

As of August 2020, 85 recognised institutional and programmatic accreditation organisations operated in the United States (some accrediting organisations are recognised only by CHEA, some only by USDE, and some by 
both). Meanwhile, 26 accreditors were not recognised by CHEA, 34 accreditors were not recognised by USDE, and thirteen accreditors were not recognised by both CHEA and USDE (CHEA, 2020).

\subsubsection{Accreditation in European Higher Education}

Quality assurance and accreditation are considered prominent reform issues in higher education worldwide. According to Serrano-Velarde (2008), since the beginning of the 1990s, countries and non-governmental organisations across Europe have discovered the potential of quality assurance to generate accountability in increasingly deregulated higher education systems. However, quality assurance in European higher education has only received significant attention since the Bologna Declaration (1999) (Amaral \& Rosa, 2010; Stensaker, 2011). This declaration defined the fundamental principles of the European Higher Education Area (EHEA) and encouraged European cooperation in higher education quality assurance through the development of comparable criteria and methodologies (Amaral \& Rosa, 2010).

The emergence of the Bologna Process and higher education institutions' increasing autonomy stimulated the establishment of Europe's national quality assurance and accreditation systems (Stensaker, 2011). Europe's development of quality assurance systems occurred quickly. Schwarz and Westerheijden (2004) reported that in the early 1990s, fewer than fifty per cent of European countries had initiated quality assessment activities at the suprainstitutional level; but, by 2003, all countries except Greece (in 2005, Asderaki, 2009) had implemented some form of national quality assurance.

Most European quality assurance systems share several significant procedural elements: internal self-evaluation; visits by external review panels; external evaluation; and public reporting (Amaral \& Rosa, 2010; Schwarz \& Westerheijden, 2004; Serrano-Velarde, 2008). However, important differences in political discourses, such as system ownership of the system and quality assurance consequences, do exist. Three European countries (France, Norway and the United Kingdom) are analysed below.

In France, the main tool for quality assurance is programme and institution evaluation. Accreditation is also used, but solely for engineering programmes. France's national quality assurance organisation is known as the High Council for Evaluation of Research and Higher Education (HCERE); it was created in 2007 and known as the Evaluation Agency for Research and Higher Education (AERES) until November 2014 (EQAR, 2017). HCERE is responsible for institutional evaluation (including higher education institutions and groups, research bodies, scientific cooperation foundations and the French National Research Agency), research unit evaluation, and bachelor, master and doctoral programme evaluation (HCERE, 2021). As mentioned above, engineering programmes are subject to separate accreditation processes administered by the Commission des Titres d'Ingénieur (Engineering Accreditation Institution) (CTI), which was founded in 1983 (Schwarz \& Westerheijden, 2004).

In contrast, Norway uses a combination of quality assurance activities that include both assessment and accreditation (for both programmes and institutions). An independent government body, the Norwegian Agency for Quality Assurance in Education (NOKUT) was established in 2002. Through assessment, accreditation and recognition of quality systems and institutions, NOKUT supervises and develops higher education quality via quality assurance systems (Stensaker, 2004, 2011).

In the United Kingdom, institutional assessment constitutes the only type of quality assurance evaluation in the country's higher education system. Created in 1997, the Quality Assurance Agency for Higher Education (QAA) provides a comprehensive service for UK higher education. It is an independent body funded through agreements with universities and colleges and contracts with the higher education funding bodies. The QAA is responsible for safeguarding public interest by applying higher education qualification standards, evaluating universities' and colleges' fulfilment of responsibilities, and encouraging continuous improvement in quality management (Brown, 2004).

\subsubsection{Accreditation of Higher Education in the Asia-Pacific Region}

The Asia-Pacific is a complex region home to a wealth of language, political, economic and cultural diversity. This results in variance in quality assurance mechanisms. Major external quality assurance models, including accreditation, assessment and audit, can be observed. Many countries have implemented more than one of these approaches in their national higher education quality assurance systems. In addition, while several countries established their systems in the mid-20 $0^{\text {th }}$ century, (for example, Japan in 1947), many other systems were only established in the first decade of the $21^{\text {st }}$ century (for example, China in 2002; Thailand in 2000) (Global University Network for Innovation, 2007; SEAMEO RIHED, 2012; Shah \& Do, 2017).

In spite of these many differences intended to reflect unique national contexts, the region's accrediting agencies and their practices each possess several common critical core elements: 
- Evaluation based on pre-determined and transparent criteria;

- A process based on a combination of self-study and peer review;

- Final decision-making;

- Public disclosure of outcomes;

- Validity of outcomes for a specific period of time (Global University Network for Innovation, 2007).

To paint a more detailed picture of accreditation in this region, the development and primary features of quality assurance in Australia, India and Indonesia are summarised below:

The Australian higher education system comprises mostly autonomous universities which have power to accredit their own courses. In 1980s, in the absence of national quality management, each individual Australian university was responsible for the development, implementation and improvement of its systems and processes for quality assurance. However, major changes were initiated in the 1990s with the release of the policy statement "Higher Education: Quality and Diversity", the creation and development of the Committee for Quality Assurance in Higher Education between 1993 and 1995, and the implementation of the Australian Qualification Framework (AQF) in 1995 (Shah, Nair, \& Wilson, 2011). The establishment of an external higher education quality assurance agency named Australian Universities Quality Agency (AUQA) was endorsed in 2000 (Anderson, Johnson, \& Milligan, 2000; Shah et al., 2011). Prior to this quality assurance processes were carried out by many agencies ustilising a range of different strategies. While this worked well for Australia's higher education system at the time, Australia adapted to international developments and recognised the need to ensure consistency among its states and territories quality assurance processes. As a result, the AUQA was established as an overarching body. AUQA adheres to an audit approach. Although the system is voluntary, any Australian higher education institution attempting to access federal funds must be audited by AUQA (Anderson et al., 2000). In 2011, The Tertiary Education Quality and Standards Agency (TEQSA) replaced AUQA. TEQSA registers and assesses higher education provider performance against its Higher Education Standards Framework (TEQSA, 2021).

In India the National Assessment and Accreditation Council (NAAC) (established in 1994) is the national quality assurance organisation. The NAAC describes its model as incorporating elements of all three quality assurance approaches (accreditation, audit and assessment). The NAAC declares whether an institution is accredited through assessment and classification of an institution on a nine-point quality scale. As noted, the organisation's methodology mandates an audit wherein a small team of external peers (mostly generalists) is sent to an institution and tasked with preparing a public report (Bhushan \& Verma, 2017; Global University Network for Innovation, 2007).

The National Accreditation Agency for Higher Education (NAAHE or BAN-PT as called in Indonesian) was established in Indonesia in 1994. NAAHE is an independent, non-structural national higher education accreditation agency that assesses institutional and programme quality against benchmark national higher education standards. The outcome of NAAHE quality assurance procedures is a formal accreditation decision graded on a four-point scale (A to D) - A indicates a course of study conforms to international standards, B indicates that a course is of good quality, $\mathrm{C}$ indicates a course fulfils minimum requirements, and D indicates the course is not accredited (Sunarto, 2017).

It can be seen that although quality assurance and accreditation policies and practices are diverse across the world, they share several common features. First of the quality assurance system is independent from the Ministry of Education (or Ministry of Higher Education) for its objective performance. Secondly, there are a variety of financial sources for quality assurance and accreditation activities. They come from the government, higher education institutions, sponsoring organisations and private foundations. Thirdly, specialized or programmatic accreditation agencies are responsible for assessing or accrediting specific degree programs for their quality assurance and continuous quality improvement.

\section{DISCUSSION AND CONCLUSION}

Quality assurance and accreditation in Vietnamese higher education is currently centralized. Quality assurance policies in the form of accreditation procedures, standards and guidelines are developed and promulgated by the Ministry of Education and Training (MOET). The Vietnam Education Quality Management Agency (VQA), which is considered the national quality assurance organization of Vietnam, is under the umbrella of MOET. Additionally, accrediting agencies, which conduct external assessment of higher education institutions and programs, and recognize their quality, were established by the MOET Minister (National Assembly, 2012). VQA and accrediting agencies heavily depend on MOET for their organizational structure, human resources and even budget for their survival and operation (Nguyen, Evers, \& Marshall, 2017). These dependences might not lead to objective assessment and accreditation results. This seems to oppose the common practices of international quality assurance. Examples from 
Australia, France and the U.S. show that the well-developed external quality assurance bodies in these countries are independent from the Ministry of Education, or even the government. Vietnam can learn from these cases to restructure its higher education quality assurance system that gives the national quality assurance organization and accrediting agencies independence and autonomy. Only when the quality assurance and accreditation get full independence and autonomy can it perform its professional missions successfully (Nguyen et al., 2017).

Vietnamese accrediting agencies only get funding from fees paid by higher education institutions for accreditation service. This has raised questions of the quality of external assessment results. Funding for accreditation agencies coming from four sources like the U.S. can be a good example for Vietnam. Specifically, all universities need to pay annual accreditation fees for a government body that distributes budget to accreditation organizations based on the number of institutions and/or programs they plan to accredit yearly.

Vietnam implements both institutional accreditation and program accreditation. However, all five Vietnamese accrediting agencies have right to conduct both of these types of accreditation and have used the same sets of assessment standards issued by MOET. Moreover, there is only a set of assessment standards applied for all higher education programs. It means that program accreditation in Vietnam is not professional accreditation and it does not reflect the content of a specific program. With program accreditation, accrediting agencies specializing in a certain area judge whether the degree program appropriately prepare graduates to enter a profession (Harvey, 2004). Obviously, Vietnam should learn accreditation policies and practices from countries having developed accreditation system like Australia, Norway and the U.S. It is advisable that Vietnam should follow the U.S. and other countries' accreditation model to promote its program accreditation. Program accreditation agencies specializing in a specific field like engineering, business, finance, or teacher training should be established as soon as possible. Furthermore, assessment sets for these programs should also developed by specialized accrediting agencies.

In spite of the fact that Vietnam's higher education quality assurance and accreditation system has been established for nearly twenty years, it has encountered several problems regarding the independence mechanism, accreditation criteria, finance and program accreditation. Best practices in quality assurance and accreditation implementation in both Western and Eastern countries might be good models for Vietnam to follow.

Acknowledgements: This research is funded by Vietnam National Foundation for Science and Technology Development (NAFOSTED) under grant number: 503.01-2019.305.

\section{REFERENCES}

Amaral, A., \& Rosa, M. J. (2010). Recent trends in quality assurance. Quality in Higher Education, 16(1), 59-61.

Anderson, D., Johnson, R., \& Milligan, B. (2000). Quality assurance and accreditation in Australian higher education: An assessment of Australian and international practice. Canberra: Department of Education, Training and Youth Affairs.

Asderaki, F. (2009). The impact of the Bologna Process on the development of the Greek quality assurance system. Quality in Higher Education, 15(2), 105-122.

Bhushan, S., \& Verma, A. (2017). Quality assurance in higher education - An Indian experience. In M. Shah \& Q. T. N. Do (Eds.), The rise of quality assurance in Asian higher education (pp. 51-66). Cambridge: Chandos Publishing.

Bowen, A. G. (2009). Document analysis as a qualitative research method. Qualitative Research Journal, 9(2), 27-40.

Brown, R. (2004). Quality assurance in higher education: The UK experience since 1992. London: Routledge Falmer.

Campbell, C. \& Rozsnyai, C. (2002). Quality assurance and the development of course programmes. Papers on higher education regional university network on governance and management of higher education in South East Europe. Bucharest: UNESCO.

Council for Higher Education Accreditation (CHEA) (2020). CHEA- and USDE- recognition accrediting organizations (as of August 2020). Retrieved from https://www.chea.org/chea-usde-recognized-accrediting-organizations

Do, Q. T. N., Pham, H. T., \& Nguyen, K. D. (2017). Quality assurance in Vietnamese higher education: A top-down approach and compliance-driven QA. In M. Shah \& Q. T. N. Do (Eds.), The rise of quality assurance in Asian higher education (pp. 51-66). Cambridge: Chandos Publishing.

Eaton, J. (2015). An overview of U.S. accreditation. Washington D.C.: Council for Higher Education Accreditation.

European Quality Assurance Register for Higher Education (EQAR) (2017). Approval of the application by High Council for Evaluation of Research and Higher Education (HCERE) for renewal of inclusion on the register. Retrieved from https://www.eqar.eu/fileadmin/agencyreports/2017-06_A38_RenewalDecision_HCERES.pdf 
Global University Network for Innovation (2007). Higher education in the world 2007: Accreditation for quality assurance - what is at stake? New York: Palgrave.

Harvey, L. (2004). The power of accreditation: Views of academics. Journal of Higher Education Policy and Practice, 26(2), 207-223.

Harvey, L. (2004-20). Analytical quality glossary. Retrieved from Quality Research International: http://www.qualityresearchinternational.com/glossary/assurance.htm

Hegji, A. (2017). An overview of accreditation of higher education in the United States. Washington D.C.: Congressional Research Service.

High Council for Evaluation of Research and Higher Education (HCERE) (2021). Missions. Retrieved from http://www.hceres.com/Agency/Missions

Kis, V. (2005). Quality assurance in tertiary education: Current practices in OECD countries and a literature review on potential effects. Paris: OECD.

Lim, D. (2001). Quality assurance in higher education: A study of developing countries. Burlington: Ashgate.

Merriam, S. B., \& Tisdell, E. J. (2016). Qualitative research: A guide to design and implementation (4 ${ }^{\text {th }}$ ed.). San Francisco: Jossey-Bass.

National Assembly (2012). Law on higher education. Retrieved from http://vbpl.vn/tw/Pages/vbpqprint.aspx?dvid=13\&ItemID=27706

Nguyen, C. H., Evers, C. \& Marshall, S. (2017). Accreditation of Vietnam's higher education: Achievements and challenges after a dozen years of development. Quality Assurance in Education, 25(4), 475-488.

Pham, N. T. T., Nguyen, Q. T., \& Nguyen, C. H. (2019). Drivers of Vietnamese higher education quality assurance. In C. H. Nguyen \& M. Shah (Eds.), Quality assurance in Vietnamese higher education: policy and practice in the $21^{\text {st }}$ century (pp. 121-136). Cham: Palgrave Macmillan.

Ramírez, G. B. (2015). Translating quality in higher education: US approaches to accreditation of institutions from around the world. Assessment \& Evaluation in Higher Education, 40(7), 943-957.

Schwarz, S., \& Westerheijden, D. F. (2004). Accreditation in the framework of evaluation activities: A comparative study in the European higher education Area. In S. Schwarz \& D. F. Westerheijden (Eds.), Accreditation and evaluation in the European Higher Education Area (pp. 1-42). Dordrencht: Kluwer Academic Publishers.

Serrano-Velarde, K. E. (2008). Quality assurance in the European higher education area: The emergence of a German market for quality assurance agencies. Higher Education Management and Policy, 20(3), 9-26.

Shah, M., Nair, S., \& Wilson, M. (2011). Quality assurance in Australian higher education: Historical and future development. Asia Pacific Education Review, 12(3), 475-483.

Southeast Asian Ministers of Education Organization Regional Centre for Higher Education and Development (SEAMEO RIHED) (2012). A study on quality assurance models in Southeast Asian countries: Towards a Southeast Asian quality assurance framework. Bangkok: SEAMEO RIHED.

Stensaker, B. (2004). The blurring boundaries between accreditation and audit: The case of Norway. In S. Schwarz \& D. F. Westerheijden (Eds.), Accreditation and evaluation in the European Higher Education Area (pp. 347370). Dordrencht: Kluwer Academic Publishers.

Stensaker, B. (2011). Accreditation of higher education in Europe - moving towards the US model? Journal of Education Policy, 26(6), 757-769.

Sunarto, K. (2017). The rise of quality assurance in Indonesian higher education. In M. Shah \& Q. T. N. Do (Eds.), The rise of quality assurance in Asian higher education (pp. 67-86). Cambridge: Chandos Publishing.

Tertiary Education Quality Standards Agency (TEQSA). (2021). About TEQSA. Retrieved from http://www.teqsa.gov.au/about

U.S. Department of Education (2021). Accreditation in the United States. Retrieved from http://www2.ed.gov/admins/finaid/accred/accreditation.html\#Overview

Vlăsceanu, L., Grünberg, L., \& Pârlea, D. (2007). Quality assurance and accreditation: A glossary of basic terms and definitions. Bucharest: UNESCO.

Williams, J. \& Harvey, L. (2015). Quality assurance in higher education. In J. Huisman, H. de Boer, D. D. Dill, \& M. Souto-Otero (Eds), The Palgrave international handbook of higher education policy and governance (pp. 506-525). London: Palgrave MacMillan. 